LOCAL WISDOM, 13 (2): 138-151, 2021
Local Wisdom Scientific Online Journal
ISSN: 2086-3764

\title{
Community Participation in Natural Disaster Mitigation Based on Local Wisdom "Adat Cao Mukak Imbo" North Bengkulu Regency of Bengkulu Province Indonesia
}

\author{
Aprianto Soni \\ Land Resource Management Study Program, University of Amal Ilmiah Yapis Wamena, \\ Indonesia \\ Corresponding Author: aprianto1488@gmail.com
}

\begin{tabular}{|c|c|}
\hline & Abstract \\
\hline $\begin{array}{l}\text { Keywords: } \\
\text { Community, } \\
\text { Environment, } \\
\text { Local Wisdom }\end{array}$ & $\begin{array}{l}\text { Environmental damage has a direct impact on human life judging by } \\
\text { environmental problems that are increasingly rampant. This damage is } \\
\text { caused by human activities that are not environmentally friendly that } \\
\text { always occur so that environmental damage does not occur } \\
\text { continuously for human life in the future need better recovery. } \\
\text { Community participation can be given in the form of thoughts/ideas, } \\
\text { materials, energy, and skills to help the success of disaster } \\
\text { management programs. The method used in this research is the } \\
\text { ethnographic method about the Rejang tribe community as the centre } \\
\text { of competency cultivation including qualitative research type. Local } \\
\text { wisdom of Cao Mukak Imbo Custom in Rejang tribal communities is } \\
\text { very rich in forms of local wisdom can be in the form of values, norms, } \\
\text { beliefs, and special rules. The form of local wisdom Cao Mukak Imbo } \\
\text { Custom is very instrumental in disaster mitigation as for the } \\
\text { prohibition contained in the local wisdom is the rule of working on } \\
\text { land steep areas or around waterfalls if we review in fact because these } \\
\text { areas are water catchment areas and when cultivated and planted } \\
\text { plants such as palawija can trigger landslides or floods. Preserving the } \\
\text { culture we have will encourage the skills and knowledge possessed by } \\
\text { local communities. Local wisdom a noble value prevailing in the } \\
\text { community's life system to protect and manage the environment } \\
\text { wisely and wisely so that the environment is maintained sustainably. }\end{array}$ \\
\hline $\begin{array}{l}\text { DOI: } \\
\text { @ } 2017 \text { The Authors. } \\
\text { Malang }\end{array}$ & \begin{tabular}{lllll} 
& Article & Received & $:$ & Dec 23, 2020 \\
\multirow{2}{*}{ ublished by GKAK UNMER } & History & Accepted & $:$ & Apr 27, 2021 \\
& & Published & $:$ & July 15, 2021
\end{tabular} \\
\hline
\end{tabular}

\section{INTRODUCTION}

The Sustainable Development Goal (SDGs) agreed in 2015 is a new change in global development. There are development goals in various aspects, one of which is the environmental aspect. The sustainable development of the environment becomes the most important aspect, including decisions related to the environment (Hoelman et.al.2015). SDGs become a new pattern in global development which is a testament to the 
concern of United Nations countries for sustainable environment development, seeing the routine of disasters that often occur as a result of human hands have occurred and spread throughout the world such as floods, landslides, abrasion, erosion, and others. The phenomenon will have an impact that will make the quality of the environment decrease and will provide a threat to the survival of human life and the surrounding environment. So it is considered very important to realize sustainable development, which is ready, safe, and resilient for life in the future.

Environmental conditions will have a direct effect on the human condition. Environmental damage is getting worse every day. The condition has directly threatened people's lives. The level of natural damage also increases the risk of natural disasters can be caused by factors, namely due to natural events and human actions. This is by Awantara (2011, pp. 205) that: "the environmental damage that occurs today also stems from human misbehaviour towards the way of view and exploration of natural resources". This kind of environmental situation is heart breaking. Human beings should maintain and care instead of the opposite of the longer the awareness is reduced to the environment. Environmental damage results in the decline and deterioration of the quality of this environment such as by the loss of land resources, water, extinction of flora and fauna, and damage to ecosystems. Higher exploitation of natural resources, higher population growth, technological developments, economic social activities regardless of carrying capacity and environmental capacity have caused environmental decline and pollution.

Environmental damage has a direct impact on human life judging by environmental problems that are increasingly rampant. This damage is caused by human activities that are not environmentally friendly that always occur so that environmental damage does not occur continuously for human life in the future need better recovery. In Article 65 point 4 of Law 32 the year 2009 environmental protection and processing, it is stated that everyone has the right and role in environmental management.

Local culture plays a role in planting values that include components of knowledge, awareness, or willingness and action to implement these values both to God, himself, between people, the environment, and nationality so that later local wisdom can become a control in living life. According to Azis (2017, pp. 2) Local wisdom is a social values that are upheld in the social structure of society. These social values serve as guidelines, controllers, and signs to behave wisely and wisely in daily life. Local wisdom that must be regulated in one cultural unity (culture) to realize the nation that is the nation of Indonesia. Habits that have shaped human behavior must be passed down for the future.

For the existence of culture to remain sustainable, one of the ways that can be taken through the integration of local cultural wisdom. The problem that occurs at this time in the community is a shift in the Rejang ethnic community caused by the current of modernization and globalization only absorbs anything that is considered a style in the present without having to think about the future. People of Rejang ethnic groups still exist who uphold the rules or habits that are considered to maintain the sustainability of the surrounding environment.

In that culture contained the value of local wisdom that has been institutionalized. The Rejang people are one of the many ethnic groups that inhabit Bengkulu Province. It is the largest and oldest ethnic group in Bengkulu. One of the areas inhabited by the Rejang 
tribe is spread in the north Bengkulu regency which comes from four Petulai and Jurai. The head of the four Petulai is called Ajai. During the Ajai reign, the Rejang people already had various customs in which there were wisdom-laden advice, wisdom values, and philosophical values in preserving and preserving the environment. Thus, seen from this aspect should be the goal of internalization so that people behave intelligently, wisely, and responsibly to the environment.

\section{METHOD}

The approach used in this study is a qualitative approach. Creswell (1998) (in Nasution, 1996, pp. 18) explaining qualitative research approach is also called naturalistic approach because field situation is natural or scientific as it is, and not manipulation according to the situation in the field. Sugiono (2011, pp. 15), concluded that qualitative research method is a method based on the philosophy of postpositivism, used to research on the condition of natural objects as opposed to experiments and key instruments as for data sampling conducted purposively and snowball. Trianggulasi collection techniques, inductive/qualitative data analysis, and qualitative research results emphasize the meaning of generalization.

Research on community participation in natural disaster mitigation based on local wisdom "adat cao mukak imbo". Methodologically this research uses a qualitative approach. According to Nasution (2003, pp. 5) "the nature of qualitative research is to observe people in their environment, interact with them, try to understand their language and interpretation of the surrounding world". The use of this approach allows researchers to directly observe the objects studied. In other words, researchers act as the main tool of research (human instrument). In accordance with Nasution opinion (1996, pp. 9) that "in qualitative research, there is no other option than to make man as the main research (key instrument)". He is the one who conducts his own in-depth observations or interviews so that he can dive into and understand the meaning of learning with the help of interview and observation guidelines.

The method used in this study is ethnographic method about the concept of society tribe Rejang as a cultural centre of competence including qualitative research types. Ethnographic research studying cultural events, presenting a living view of the subject of the study, is a model of social sciences research that uses the foundation of phenomenological philosophy. According to Densim, (2000, pp. 457) ethnographic research describes how to think, how to live, how to behave as a social settings study. Ontological perspective of nature of the phenomena or entity and social reality becomes very important in conducting ethnographic research process. Qualitative researchers are mainly very concerned with the process compared to outcomes or products

Creswell (1994, pp. 142) describes ethnographic research systematically conducting descriptions, analyses, and interpretations by living the interactions and perceptions of the people studied instead of the perceptions or wishful thinking of researchers. Sociocultural behaviors and practices in all forms of interaction, communication, rules, morality, and belief systems are described as being in everyday life. Creswell, (1994, pp. 145) reaffirmed that ethnographic research focuses on the community, selecting informants who are known to have a broad and deep view of the activities of the society being studied, as well as emphasizing the meaning of how community make sense of his 
life, experience, and the structure of his own world. According to Mason's explanation (2006, pp. 120) explaining the identification and selection of the right informant will strengthen access to data sources relevant to the question of ethnographic research conception of the community tribe Rejang as a centre for cultivating competence to review and present the best experiences of best practice about interactions, relationships, and socio-cultural situations, socio-cultural practices, indigenous organizations. From this study, it is expected that researchers can obtain accurate information and data for the study, another reason why researchers choose naturalistic-approach is because the data that will be obtained from this study in the field is more about the actions and expressions of words from respondents who as much as possible are natural, without any engineering and outside influence.

\section{RESULTS AND DISCUSSION}

\section{Result}

The geographical condition of North Bengkulu Regency is mostly with an altitude below $150 \mathrm{~m}$ above sea level, there is a west side stretching in the direction of the coast from south to north, while in the eastern part of the topography is hilly with an altitude of $541 \mathrm{~m}$ above sea level. The amount of rainfall is influenced by climate, geographical conditions, and water current rotation. North Bengkulu Regency generally has a very varied topography ranging from plain to hilly. The area is flat only in urban areas and the hinterland of Arga Makmur City. The area with an altitude of $10-150 \mathrm{~m}$ above sea level is located in the eastern part is a hilly area with an average height of 541 meters from sea level. Topographical condition is the main factor that has the most effect on environmental damage when compared to other factors. The topography in question is stated in the slope percent, the greater the slope the greater the risk of environmental damage.

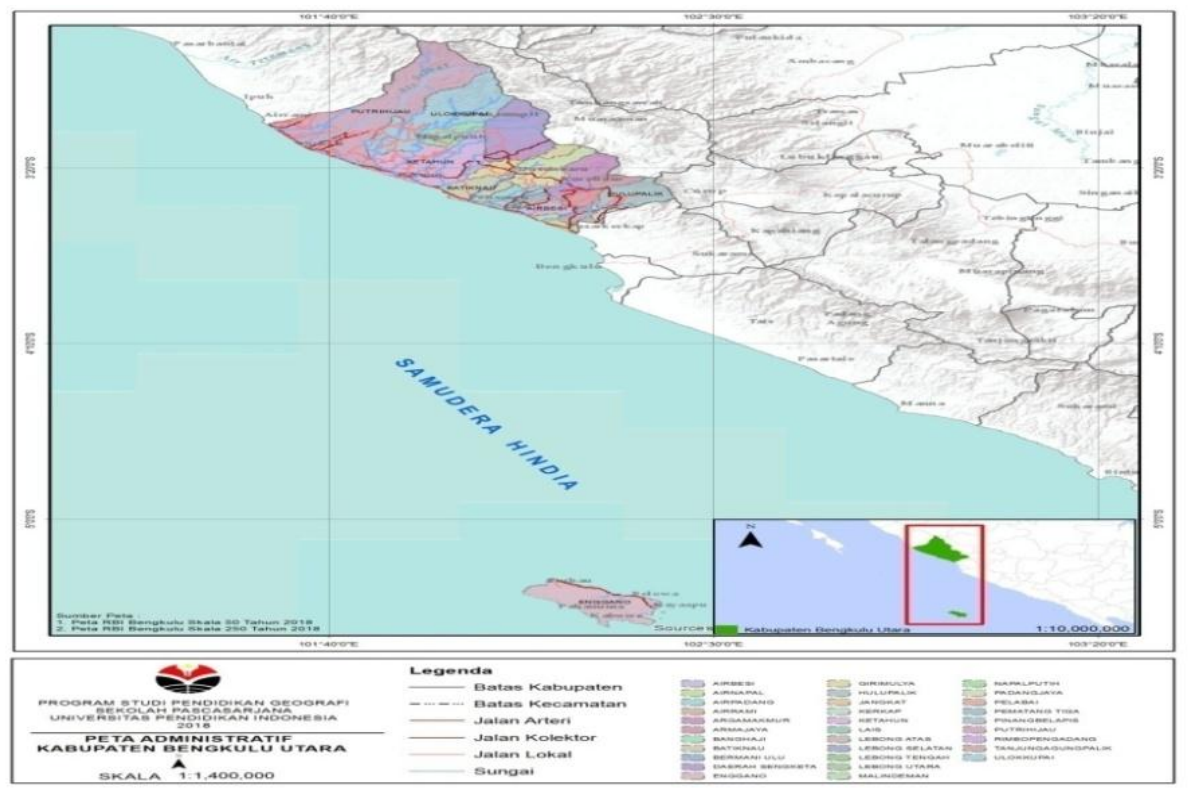

Figure 1. Aadministrative Map of North Bengkulu Regency Source: Aprianto Soni Design (2019)

Data on the amount of rainfall in North Bengkulu Regency from 2010 to December each month ranges from 161-750 mm, with an average monthly of $390.75 \mathrm{~mm}$. in 2010 , high rainfall occurred in July and March, namely $698 \mathrm{~mm}$ and $750 \mathrm{~mm}$. By looking at such 
rain patterns, and following the global climate pattern, the area of North Bengkulu Regency is classified to regions with a relatively wet tropical climate without dry season, which is given the symbol Af (following the criteria Koppen and following the classification according to Schmid da Ferguson according to Oldeman and according to Mohr). This type of wet tropical climate has the potential for agricultural development. But on the other hand with the character of topography/morphology of the area above, there must be protected areas in the form of areas that protect the lower areas, specially protected forest areas, and water absorption areas.

The condition of the land in North Bengkulu Regency consists of several types of

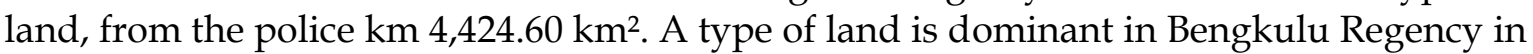
the north and is an association of latosol andosol ha 169,008 ( $30.46 \%)$, regosol of Ha $166,970$ ( $30.10 \%)$ and padsolic red yellow PMK of Ha 72,914 ( $13.14 \%$ ) and brown padsolic association and pmk litosol of / Ha 39,352 ( $7.06 \%$ ). Factors that can affect the agricultural sector especially for the selection of the type of crop to be planted. The factors are soil type, soil texture, soil ph, and soil color. According to the development and development of progress, the occurrence of land use through legal procedures for the purposes of land development is built and not built. Most of Bengkulu in the northern district is still dominated by forests, agricultural cultivation, shrubs with a small proportion of degraded land.

In mountainous areas, forest conditions are mostly found. Most of them are in high altitude areas with land slopes above $25 \%$, while the middle part consists of built-up forests. Overall availability of natural resources in North Bengkulu Regency is quite potential but due to various limitations to date cannot be utilized optimally. North Bengkulu Regency is an agricultural and plantation area where the main livelihoods of its residents are in the agricultural and plantation sectors. This is because the largest area is the area used for agriculture and plantations. Land Cover in North Bengkulu Regency includes forests, built-up forests, shrubs, plantations, rice fields.

North Bengkulu is one of the districts with the largest transmigration settlement area in Bengkulu. The transmigration locations are, Padang Jaya District, Giri Mulya District, Ketahun District and Putri Hijau District. So it is not surprising that Javanese is one of the most heard languages besides Rejang which is a local indigenous tribe. The rate of population growth in the North Bengkulu Regency is strongly influenced by trade and service activities that absorb a lot of labour. Especially in Arga Makmur, Lais, Ketahun and Padang Jaya sub districts. This indicates the rapid growth of urban centres of activity, such as trade and services, so that the population who originally resided in the centre of activities will shift to an area far from the city centre, as a result of the transfer of land use functions from residences to trade and services.

The human relationship with the environment ethically environment, able to manage, utilize, and preserve the environment, one form of environment that is wise and wise is included in the form of local wisdom of the Rejang tribe. Realized in the form of ideas, ideas, processes that should be done. Such as land use, springs, streams, and conservation of the environment. The main objective is efforts to maintain the sustainability and sustainability of the environment around the Rejang people. From the form of local wisdom that has become a habit and procedures of life of the community that is carried out in everyday life persists in the middle of the habit of doing damage or 
disruption to the existence of the available environment, meaning that the form of local wisdom of the Rejang tribe community has been tested over time and overtime and can reduce the negative impact on the existing natural environment.

Human understanding of the environment should be emphasized on the local wisdom of the community in efforts to preserve the natural environment so that a human harmony to the existence of the natural environment will provide a good life. Furthermore, local wisdom that appears in one system of life in the community is the value of local wisdom itself. The value contained in the form of wisdom towards the environment, the value that is believed to have a perception in activities with the environment both individuals and groups is the actualization of the culture created by man so that it becomes a local culture will play a role to the environment because human beings in every human interaction with the environment have a purpose in the human process to create conditions conducive to the existence of natural resources in the environment for the sustainability of human life. Through the values contained in it, if it continues to be applied in daily life, it will also be maintained in human life until the next generation.

The human relationship with nature as its environment is a system that cannot be separated from each other, human beings are in an environment and there is human life. Human beings have an important and meaningful role in the environment on earth, as a whole unity and should be in an environment to think about and provide environmental conditions that are harmonious, balanced, and sustainable between human life and the environment. In maintaining balance with the community environment do norms, values, or rules that have been in force for generations which is local wisdom. Some forms of local wisdom in the Rejang tribe in conservation activities include "adat cao mukak imbo".

Indigenous Rejang planned, when there are children kutai who wanted to open up land in of the jungle (mukak imbo) to tree crops or agricultural land, villagers are helping them slashing and cut down the forest trees to open to be changed into tree crops and agriculture. Usually, a kutai assisted by the kutai (community) open land is someone who just settling down, a young couple will start their businesses and must be guided by parents. Before open land should invite local communities to their being composed of village officials to hold the meeting (basen kutai). During the discussions at the start with host provided betel leaf (dawen iben pamit) to the village head (patai) to begin an event (basen) having leaves sirih (dawen iben) acceptable by the village head (patai) and begin. Meetings were calculated area of forest will open the day and date forest whoever felling and head of the group who will be leaving to the forest. In the deliberation there food is rice with an arbor (punjung) the thigh chicken and rice with coconut sweet white glutinous goring (sawo bungai). And meetings village head (patai) convey some regulation which must be obeyed by the open woodlands as land to cultivate among others:

1) Every forested land clearing for plantations, agriculture must have permission from the village head and local government.

2) Each owning arable land must mark the limit of ownership in the form of bamboo plants (buluak seik) or given a stake that later can grow like res wood (kyeu res). However, if the newly opened forest is usually only marked with bamboo that is stuck to the land (sulo).

3) Every land produced must-have plants. 
4) Land that has no plant time limit of 3 (three) years, then the land is again owned by the community (kutai).

5) Within 40 (forty) depa from the edge of the river as well as from the spring should not be cut down forest let alone cultivated.

In local wisdom on how to open forest or land (cao mukak imbo custom) there are recommendations from the Rejang Tribe that contain philosophic value and public awareness of the importance of preserving nature or the environment, such as:

1) The act of simbur cahayo, this law made by holland and we do some changes of the in by Rejang bermani in is one source of the act of customarily written dispute resolution used as a reference in-ground or land occurring in the community.

2) Imbo betungau, this mention one who is to woodland penunggu (ghost) unseen so there is some a prerequisite to open this area is often to community open woodlands that you. Not open woodlands that you by the community, nature becoming sustain environment and disasters. According to an informant named Mr. Odok stated that the village of Aur Gading in the Dutch era was a forest of prohibition. As a prohibited forest, a kind of barrier is installed called Bewesen by the surrounding community. Bewesen is a forest barrier that can be worked by the community. Bewesen has undergone changes so that logging is increasingly rampant. This is not in accordance with local wisdom. The transfer of forest barriers has resulted in the forest becoming bare, landslides in the river. One of the evidence of the result of forest damage is the erosion of the river banks, even Dutch heritage dams have begun to be damaged.

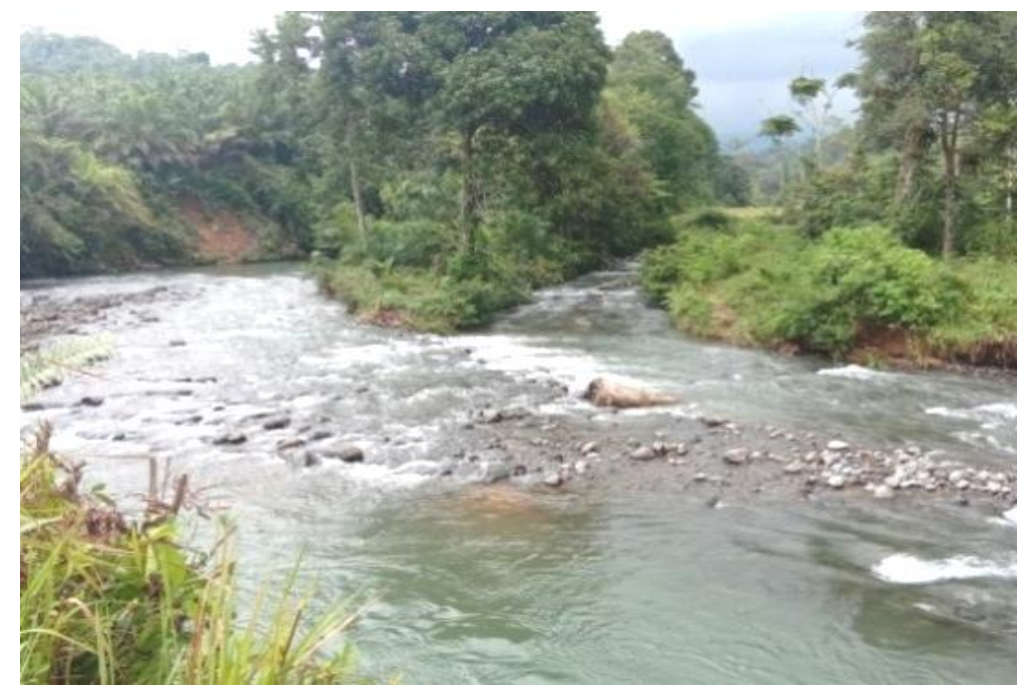

Figure 2. Erosion Conditions by the River Source: Research Dock (2019)

3) Megeges, One of the habits of the Rejang tribe to clean the land by burning, the purpose of this activity is actually to prevent the fire when burning the new land. The other land is burned or engulfed other people's fields, in the process of gas and burning carried out mutually by cleaning the surroundings of the new arable land. 
4) Sulo, a kind of prohibition sign or a sign to have forest products that still have not produced, namely a bamboo stick pierced into the ground whose top is broken in two and between the shards inserted another bamboo.

5) Sakea arable land that has re-formed the forest, according to his advice, sakea deliberate because the soil will one day expire its fertile period, and it will take some time to restore the fertility of the arable land. Over time, the land will become a forest again this concept is often called moving fields.

6) Jamai, More or less the same as sakea, the fields will be abandoned after the old season and deliberate but still taken from young crops such as efforts to increase food production by creating diversification or diversity. Usually crops are used as interspersed crops after farmers have finished producing one type of food sourcen examples of corn, soybeans, cassava, sweet potatoes, and peanuts.

In addition to some of the above local advice and wisdom, several other restrictions are concerned with the natural environment around the Rejang people. Wood that if cut down then forms a bridge between two springs forbidden to be cultivated will pose a danger and disaster to the owner, in the second modern conservation system between it is known as the river borderline. Similarly, the land where the wood is cut down will slide away because the steep slopes are also prohibited to be worked on. The area around the waterfall (curup) is also prohibited to be managed by the community because there is a belief of supernatural influences around the area if we review it. This area includes water catchment areas, when cultivated crops such as corn, soybeans, cassava, sweet potatoes, and peanuts cancause landslides.
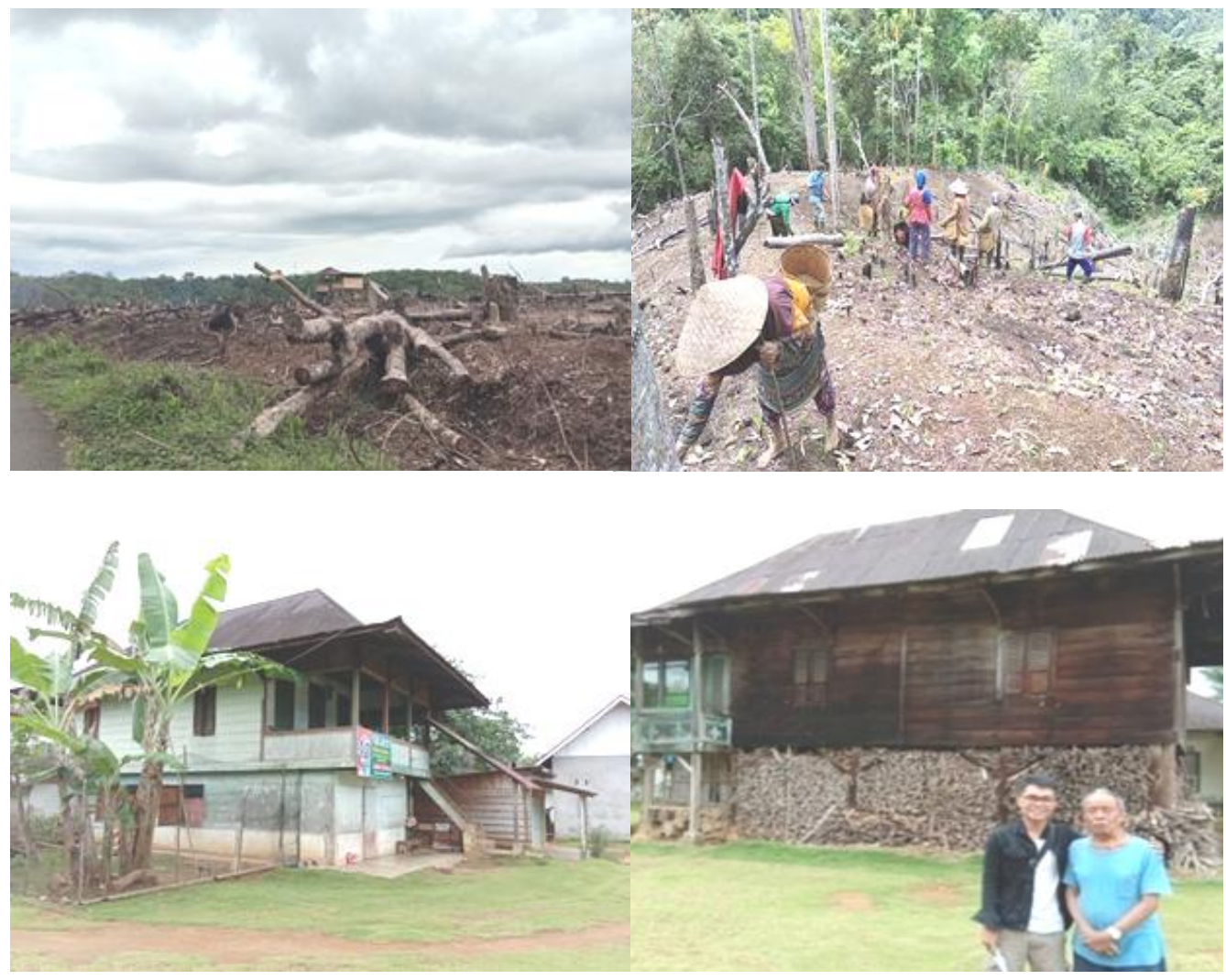

Figure 3. Conditions of forest land that has been opened for agricultural activities and building houses Rejang tribe North Bengkulu

Source: Research Dock (2019) 
The People of Rejang tribe in ancient times believed that the places that existed waiters in the area of land that would be opened. Like large stones, in the big trees, there are waiters, as well as the jungle is believed to have inhabitants. Before the forest (imbo) was cut down and cleared for agricultural land and plantations at the location was first held "kedurai bumai" to say goodbye and the spirits of the residents and rulers around it were asked to move to find another place. There is also a Rejang community by doing the name Menabes or putting a machete on a tree that will be opened to be used as a field. If the machete is missing which was placed yesterday means that the land should not be worked and if there is still a machete in the tree it means that the area can be worked on.

The community comprehensively manages and preserves the proper environment to avoid the loss materially with ourselves and the proper environment. The value of mitigation is integrated with the human capacity to manage a proper environment based on the ability of science and experience somewhere on the condition of land that spans the threat of disaster risks. The environmental conditions that will affect and influenced human life init. Review of the risks come from human activity that will cause floods, landslides, erosion, etc. the anticipation before the incident is a step in disaster mitigation. The relationship human behaviour against the natural environment that is been relegated to the local tribes have Rejang value, disaster mitigation of them:

a) Wood that if cut down then forms a bridge between two springs then the area is prohibited to be cultivated will pose a danger and disaster for the owner, in the modern conservation system both sides of it is known as the borderline of the river.

b) Similarly, the land where the timber is cut down will slide away due to steep slopes are also prohibited to be cultivated resulting in erosion if cultivated.

c) The areas around the waterfall (curup) are also prohibited to be managed by the community because there is a belief in supernatural influences around the area. Prohibition of working on steep areas or around waterfalls if we review because these areas are catchment areas and when cultivated and planted plants such as palawija can trigger landslides.

The form of the idea, the one conducted, and forms that real in treating object components forest above, it can be seen that in preventing the disasters as landslide and erosion preventable through the move of maintaining the regions latitude slope down to the region's mountains, reduce the threat of triggered landslides and sedimentation in a stream river. From the notion of, the process that can be done and forms that real was conscious effort done of the community to prevent the disasters in which to come.

The form of preservation carried out by the community on the local wisdom of the Rejang tribe contained the value of local wisdom in it is interpreted as an effort to preserve the environment in components such as forests, springs, land use, and river flows, which has the main objective of efforts to maintain sustainability and sustainability. Conservation actions carried out by the community are not considered local wisdom, because the community is accustomed to doing such actions and forms so that it becomes a culture among the local community. So if the information form and value of local wisdom contained therein is associated with environmental conservation efforts are very likely to be implemented in daily life generally for the public at large and especially for the world of education. 
In Kabupaten Bengkulu North very often earthquakes occur, people have long understood how to minimize the impact of each disaster and avoided. The Rejang people themselves already have local values that if reviewed and interpreted teach the community to be ready in the face of disasters. One of them is urged to avoid fires, as well as a ban on cutting down or clearing certain areas of land so as not to erosion and landslides and damage the springs. As noted above that this community of Rejang disaster mitigation will already know. Disaster mitigation, consisting of the disaster mitigation and, definition according to the ministerial decree in mitigating the Indonesian no. 31 years 2003 which means efforts and activities to reduce and minimize the impact caused them, covering preparedness and vigilance. While the act no disaster in 24 years 2007 explained that:

"Disaster is an event or series of events that threaten and disrupt people's lives and livelihoods caused, both by natural and non-natural factors and human factors resulting in human casualties, environmental damage, property losses, and psychological impacts".

Based on two explanation, it is known that disaster mitigation is an attempt to reduce and minimize the occurrence of natural phenomena, social resulting in a loss of human and proper environment, as disaster mitigation by definition described in article no 24 years 2007, which is a series of efforts to reduce the risks, either through physical development as well as raising of awareness and increasing the capacity to face the threat of a natural disaster.

\section{Disccusion}

The Rejang tribe is one of the oldest ethnic groups in Sumatera, has a clear line offspring, customs and high living ordinances among hundreds of ethnic groups on this archipelago. Culture of the Rejang tribe, such as the history of language, script, system knowledge, social organizations, live equipment system, technology, livelihood systems, religious systems and the arts. Rejang tribe is the oldest tribe that inhabits most of Bengkulu province spread across five kabupaten: Lebong, Rejang Lebong, Kepahiang, central Bengkulu and North Bengkulu. The number of members is approximately $1,190,418$ people or $60.36 \%$ of the total population of Bengkulu Province of 1,972,196 people and has its own culture that needs to be known not only by the local community but also the outside community of the Rejang tribe. The local community has an interest in not being deprived of its own cultural roots because the culture belongs together. A number of ideals, values and standards of behavior, so that the individual in it can be understood by his group. While the outside community has the interests of various aspect bothinclude knowledge, beliefs, art, law, morals, habits so that the community can adjust, learn the cultural benefits of the Rejang tribe and develop it for the common good in daily life.

It is important to note together that culture is the result to learn not inherited. Koentjaraningrat (1982, hlm.9), suggested that an idea and work of human culture, by learning to familiarized, and the whole of the prudence and that his work. Learning from one generation to the next (enculturate) unwittingly culture change will happen. And also culture Rejang from ancestors would have had to current generation changes can occur due to a new invention, the entry of outsiders, or the behaviour modification and value in the culture itself. Here how the was presented by giving facts history convincing. Phase by phase described with the help of numbers years although not exact, when approaching right as the basis of the changes taken place and why it can happen. 
Change the culture from one stage to the next stage requires a balance between individuals and society. When one of the more dominant causes to change the culture of having a negative way earthquake so with the behaviour anti-social, such a crime, abuse narcotics, violence, conflict between societies. To keep change direction is still in the line, balance enculturate through the posts like this indispensable by all parties both support that culture herself or stakeholders. Stakeholders politics, tradition community figures, clergy will comprehend culture, the central bank would the implementation of individual behaviour or group on would be competition. Competitive culture to provide room for achievement, the quality of, creativity and the spirit of good in the clamorous abuse and the protrusion of interests of an individual or group.

From the elements, culture can be seen value which is still to be defended and which ones need adaptation environment and which is who should be expanded. Of cultural preservation dynamic as it satisfies needs identified community members with values. According to Wikantiyoso (2010, pp. 26) Local knowledge and ecological wisdom in mitigating natural disasters are owned by local areas. Culture itself Characteristics as the Rejang stay can be maintained and can be recognized even a little whatever the progress achieved. Do not get characteristics that have gone up in an era without having any business or an attempt to try to take heed, when your own culture is more qualified than culture elements beyond which are not necessarily better.

The authenticity and privileges of Rejang today are very much studying the scientists based on majesty the elements culture integrated with a culture of Rejang itself. Before we look at the customs and culture of Rejang, it is good we understand briefly and clear the history and origins of the peoples Rejang itself. Tracing the trail of the origin nations Rejang we must look back to the history of Indonesian ancestors. The ancestor of the Indonesian nation who sends down a variety of diverse tribes and language and culture that spread from west of Sumatra further east Papua allegedly derived from the Asian continent, exactly the Yunnan, south china. It is consistent with the opinions of Von Heine Geldem (in Cecep Eka Permana (2004, pp. 299) that the ancestor's Indonesian nation is derived from the plains Yunnan, southern china with posited evidence similarities objects relic of an axe, square the axe tapering between regions Yunnan and Indonesia.

Local knowledge is getting fade over time progress now the world primary education and rarely use local knowledge as a source of learning for people who do not know it will the existence of value Rejang tribe in the local culture. Teaching us value local knowledge is around the neighbourhood and a growing awareness of caring environment students in handling the disaster, how to deal with disasters and also and anticipate that can be carried in mitigation action in dealing with disasters through local knowledge. Learning based on values wisdom local insightful sustainable development in terms of realizing the community faced the future and wise and wise towards the local environment. In local knowledge of Rejang, there are three scores of local knowledge as conservation rules in open of forest and land.

Through the value of the local is expected to students can dig and preserve the local culture. Borrow opinions Surasmi (2013, pp. 618) said that children nation this country a given for and should have been introduced to the environment most close to his village, sub-district, district after that new. International and national level by studying the local 
culture will people understand what kind of activity for the environment as taught people passed away.

With the implementation of local as wisdom, the directive is expected to be expected society had attitudes and action that continuously feel have a role and an obligation to keep Indonesian culture and conservation feel responsible to always protect the cultural heritage that has existed since ancient. As well as attitude reflect concern that any action taken will always affect the environment so it always trying to do that no harm to environmental sustainability. According to Irianto (2009, pp. 3), based education can be said of the local education as a model that has a high resolution for the development of life skills by focusing on skills and potential of local empowerment in the respective area.

Planting and were then to develop an attitude or concerned with the environment which we inhabit the activities carried out by daily. To get used to always care about the environment should be the role of the people started from the family environment, school. On the importance of protecting the environment so that young people are human and physical and spiritually healthy. Local knowledge of Rejang in developing character care about the environment became one of the alternative solutions to the world education following the local owned the Rejang North Bengkulu district to prevent and reduce the problem of existing environmental disaster mitigation, both the social and physical environment.

\section{CONCLUSION}

Based on the results and findings obtained in the field about community participation in natural disaster mitigation based on local wisdom "adat cao mukak imbo", there are activities of Rejang people who synergize with the environment. In the community activities there is a form, idea, idea, and process of the local community as environmental preservation.

The form of local wisdom based on the experience and knowledge of the Rejang people in North Bengkulu Regency as the value of life is considered correct so that it can be conveyed to the next generation. The results showed that the participation of Rejang people in disaster mitigation has been arranged for generations and is still maintained until now, namely the local wisdom of cao mukak imbo or ordinances in clearing land, as for the prohibition that should not be done by the community, namely opening forests or land on the banks of rivers, springs and waterfalls because the area is a catchment area. People should not cut down trees around steep slopes because it can cause landslides.

Efforts made by the community to preserve the local wisdom of the Rejang tribe through moral messages contained in the advice on conservation include the law simbur cahayo (land dispute rules), imbo betungau (forest prohibition), sulo (sign of prohibition), mengeges (clearing land), sakea (reforestation) and jamai (planting crops). These admonitions are able to minimize environmental damage so that the community can treat nature wisely and wisely as an effort to foster an attitude that reflects concern for the environment 


\section{REFERENCES}

Azis, Baskoro (2017) Kearifan Lokal Masyarakat Kampung Wisata Kerajinan Tangan di Dusun Rejoso Kota Batu (Local Wisdom of Handicraft Tourism Village Community in Rejoso Village, Batu City. Local Wisdom, 9 (1): 1-11

Creswell. John. W. (1994). Research Design Qualitative \& Quantitative Approaches California: Sage Publications.

Creswell. John. W. (2010) Research Design: Pendekatan Kualitatif, Kuantitatif Dan Mixed (Qualitative, Quantitative and Mixed Approach) Yogyakarta: Pustaka Pelajar.

Denzim, N.K, \& Lincoln Y. (2004). Handbook of Qualitative Research Second Edition. London: Sage Publications, Inc.

Hoelman, et al. (2015). Panduan (Guide) SDGs: Untuk Pemerintahan Daerah (Kota Dan Kabupaten) Dan Pemangku Kepentingan Daerah (For Municipal and District Government and Local Stakeholders). Internasional NGO Forum on Indonesian Development.

Mason, J. (2006). Qualitative Researching. London: SAGE Publications Ltd.

Spradley, J.P. (1980). The Ethnographic Interview. Fort Worth, TX: Harcourt Brace Jevanovich College Publisher

Spradley, P. (2007). Metode etnografi (Ethnography Method). Yogyakarta: Tiara wacana

Spradley. J. (1980). Participant Observation. New York: Holt, Rinehart and wiston.

Awantara, I. G. P D. (2011). Peran Etika Lingkungan dalam Memoderasi Pengaruh Kepemimpinan dan Budaya Organisasi Berwawasan (The Role of Environmental Ethics in Moderating the Influence of Leadership and Culture of Insightful Organizations). Jurnal Ekosains. Vol. 3 (2). Hlm 105-120. Tersedia di http://jurnal.pasca.uns.ac.id/ indeks.php/ekosains/article/view/287/271.

Maryani, Enok Dan Yani, Ahmad (2016). Kearifan Lokal Masyarakat Sunda dalam Memitigasi Bencana Dan Aplikasinya Sebagai Sumber Pembelajaran IPS Berbasis Nilai (Local Wisdom of Sudanese People in Mitigating Disasters and Their Application as a Source of Value-Based IPS Learning). ISSN $1412-565 \times$ diakses http://jurnal.upi.edu/proceedingfptk/author/enok-maryani.

Wikantiyoso, Respati (2010). Mitigasi Bencana Di Perkotaan; Adaptasi atau Antisipasi Perencanaan Dan Perancangan Kota? (Potensi Kearifan Lokal Dalam Perencanaan Dan Perancangan Kota Untuk Upaya Mitigasi Bencana) (Urban Disaster Mitigation; Adaptation or Anticipation of City Planning and Planning? Potential Local Wisdom in Urban Planning and Planning for Disaster Mitigation Efforts). Local Wisdom. II(1):18-29

Watzh, M. H. (2010). An Assesment of Character Education in New York State. D'Youville College. Dissertation.

Irianto, Agus Maladi. (2009). Mahasiswa dan kearifan lokal (Students and local wisdom). Tersedia (ready) http://staff.undip.ac.id/sastra/agusmaladi. Diakses tanggal 17 Oktober 2018 
(2004). Undang-undang No.24 Tahun 2007 tantang Penanggulangan Bencana

Republik Indonesia (Law No.24 of 2007 challenges Disaster Management of the Republic of Indonesia: UUD

Undang-Undang Republik Indonesia Nomor 32 Tahun 2009 Tentang Perlindungan Dan Pengolahan Lingkungan Hidup (Law of the Republic of Indonesia Number 32 of 2009 concerning Environmental Protection and Processing).

Menteri dalam Negeri Republik Indonesia (Minister of Home Affairs of the Republic of Indonesia). (2003). Keputusan Menteri Dalam Negeri Nomor 131 Tahun 2003 Tentang Pedoman Penangulangan Bencana dan Penanganan Pengungsi di Daerah Menteri Dalam Negeri. (Decree the Minister of Home Affairs No. 131 of 2003 concerning Guidelines for Disaster Management and Handling of Refugees in the Regional Minister of Home Affairs). Republik Indonesia (Republic of Indonesia): Mendagri.

Badan Pusat Statistik Kabupaten Bengkulu Utara (Central Statistics Agency of North Bengkulu Regency) (2015). Data Kependudukan Kabupaten Bengkulu Utara (Population Data of North Bengkulu Regency) (2015). Kabupaten Bengkulu Utara (Regency of North Bengkulu):BP. 